\title{
SAR11 Cells Rely on Enzyme Multifunctionality To Metabolize a Range of Polyamine Compounds
} \author{
Ferdi L. Hellweger, ${ }^{d}$ (D) Stephen J. Giovannoni ${ }^{a}$ \\ aDepartment of Microbiology, Oregon State University, Corvallis, Oregon, USA \\ bDepartment of Chemistry, Oregon State University, Corvallis, Oregon, USA \\ cDepartment of Botany \& Plant Pathology, Oregon State University, Corvallis, Oregon, USA \\ dWater Quality Engineering, Berlin TU, Berlin, Germany
}

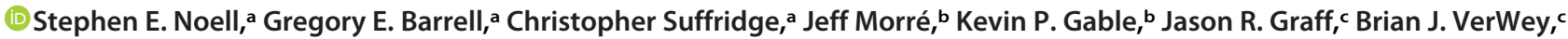

ABSTRACT In the ocean surface layer and cell culture, the polyamine transport protein PotD of SAR11 bacteria is often one of the most abundant proteins detected. Polyamines are organic cations at seawater $\mathrm{pH}$ produced by all living organisms and are thought to be an important component of dissolved organic matter (DOM) produced in planktonic ecosystems. We hypothesized that SAR11 cells uptake and metabolize multiple polyamines and use them as sources of carbon and nitrogen. Metabolic footprinting and fingerprinting were used to measure the uptake of five polyamine compounds (putrescine, cadaverine, agmatine, norspermidine, and spermidine) in two SAR11 strains that represent the majority of SAR11 cells in the surface ocean environment, "Candidatus Pelagibacter" strain HTCC7211 and "Candidatus Pelagibacter ubique" strain HTCC1062. Both strains took up all five polyamines and concentrated them to micromolar or millimolar intracellular concentrations. Both strains could use most of the polyamines to meet their nitrogen requirements, but polyamines did not fully substitute for their requirements of glycine (or related compounds) or pyruvate (or related compounds). Our data suggest that pot $A B C D$ transports all five polyamines and that spermidine synthase, speE, is reversible, catalyzing the breakdown of spermidine and norspermidine, in addition to its usual biosynthetic role. These findings provide support for the hypothesis that enzyme multifunctionality enables streamlined cells in planktonic ecosystems to increase the range of DOM compounds they metabolize.

IMPORTANCE Genome streamlining in SAR11 bacterioplankton has resulted in a small repertoire of genes, yet paradoxically, they consume a substantial fraction of primary production in the oceans. Enzyme multifunctionality, referring to enzymes that are adapted to have broader substrate and catalytic range than canonically defined, is hypothesized to be an adaptation that increases the range of organic compounds metabolized by cells in environments where selection favors genome minimization. We provide experimental support for this hypothesis by demonstrating that SAR11 cells take up and metabolize multiple polyamine compounds and propose that a small set of multifunctional enzymes catalyze this metabolism. We report that polyamine uptake rates can exceed metabolic rates, resulting in both high intracellular concentrations of these nitrogen-rich compounds (in comparison to native polyamine levels) and an increase in cell size.

KEYWORDS SAR11, marine microbiology, metabolism, physiology, polyamines

olyamines are low-molecular-weight organic polycations that are ubiquitous in living organisms. They play a role in stabilizing DNA, RNA, and proteins, are required for cell growth, and have been implicated in biofilm formation (1-3). Polyamine compounds and concentrations vary between cell types and can depend on nutrient status,
Citation Noell SE, Barrell GE, Suffridge C, Morré J, Gable KP, Graff JR, VerWey BJ, Hellweger FL, Giovannoni SJ. 2021. SAR11 cells rely on enzyme multifunctionality to metabolize a range of polyamine compounds. mBio 12 e01091-21. https://doi.org/10.1128/mBio .01091-21.

Editor Nicole Dubilier, Max Planck Institute for Marine Microbiology

Copyright $\odot 2021$ Noell et al. This is an openaccess article distributed under the terms of the Creative Commons Attribution 4.0 International license.

Address correspondence to Stephen J.

Giovannoni,

steve.giovannoni@oregonstate.edu.

Received 12 May 2021

Accepted 16 July 2021

Published 24 August 2021 
temperature, and salinity (4). Polyamines are found at low nanomolar concentrations in the coastal and open ocean, reaching maximal concentrations of $30 \mathrm{nM}$ during algal blooms, but typically are around $1 \mathrm{nM}$ (5-7). Polyamines from the environment are metabolized by bacteria as nitrogen and carbon sources at rates similar to those of dissolved free amino acids and supply up to $14 \%$ of bacterial nitrogen demand in coastal regions (8-10).

Putrescine (PUT) and spermidine (SPD), the most abundant polyamines in the oceanic dissolved pool, are typically 3 to $5 \mathrm{nM}$ in the environment, but spermine, cadaverine (CAD), and norspermidine (NSD) have been detected at lower levels $(6,10,11)$. Several other polyamines, such as 1,3-diaminopropane (DAP), agmatine (AGM), homospermidine (HSD), spermine, and larger, more complex polyamines are known to be produced and/ or metabolized by cells from all domains of life $(3,4,9,12,13)$. Metabolic pathways for common polyamines are shown in Fig. 1.

SAR11 alphaproteobacteria make up the majority of bacteria in the ocean (14). SAR11 cells primarily utilize labile, low-molecular-weight molecules (15). They pack their relatively large periplasmic space (16) with large numbers of $A B C$ transporter substrate-binding proteins (SBPs) $(17,18)$, increasing the encounter rate and binding of substrate molecules with SBPs, resulting in high whole-cell uptake affinities $(19,20)$. Recent modeling work has extended this observation, suggesting that this strategy may contribute to the low growth rates of SAR11 cells (21). SAR11 bacteria evolved minimal genomes in response to streamlining selection, which favors efficient use of resources in nutrient-limited ecosystems (22). Enzyme multifunctionality, defined broadly as enzymes that are adapted to carry out more than one function $(23,24)$, and particularly enzymes that are adapted to have broader substrate and catalytic range than normal, has been hypothesized to reduce gene content in streamlined cells and has been confirmed for the SAR11 glycine betaine transporter (20). Here, we use multifunctionality rather than promiscuity to differentiate enzymes that interact with multiple substrates at a single catalytic site in response to evolutionary pressure (25). This retains promiscuity for describing enzyme interactions with substrates that are not under evolutionary pressure.

SAR1 1 cells produce large numbers of PotD, the SBP involved in polyamine transport, both in cultures and the environment, making it the most highly expressed transporter for N-related compounds by SAR11 cells $(17,18,26)$. N-limited cultures of SAR11 strain HTCC1062, a member of the cold, high-latitude group la.1 ecotype, did not upregulate genes for polyamine transport or metabolism, except for an enzyme implicated in PUT and CAD metabolism (27), but genes involved in the metabolism and transport of other organic N sources were upregulated (27). Incubation experiments with natural seawater communities provided evidence that SAR11 cells may sometimes respond to additions of the polyamines PUT and SPD; transcripts for SAR11 genes involved in polyamine metabolism increased in the first hour of incubation and accounted for over a quarter of all transcripts (28). In other experiments with PUT and SPD amendments to seawater, it was observed that SAR11 cell abundance did not change during a 48-h period in response to PUT and SPD addition $(29,30)$; oligotrophs frequently decrease in relative abundance in incubation experiments due to their low growth rates, while copiotrophs increase rapidly due to their high growth rates under high nutrient conditions used in incubation experiments (15).

In this study, we used targeted metabolic footprinting and fingerprinting to examine the types and amounts of polyamines taken up and metabolized by two SAR11 strains. Both strains of SAR11 used in this study come from the la subgroup; "Candidatus Pelagibacter ubique" HTCC1062 belongs to the cold, high-latitude group la.1 ecotype, and "Candidatus Pelagibacter" strain HTCC7211 is from the equatorial, warm water la.3 ecotype (15). Targeted metabolic footprinting uses liquid chromatography tandem mass spectrometry (LC-MS/MS) to measure changes in the concentrations of specific metabolites dissolved in spent culture media (31), while fingerprinting quantifies the concentrations of targeted metabolites within cells (32). We hypothesized that SAR11 cells would 


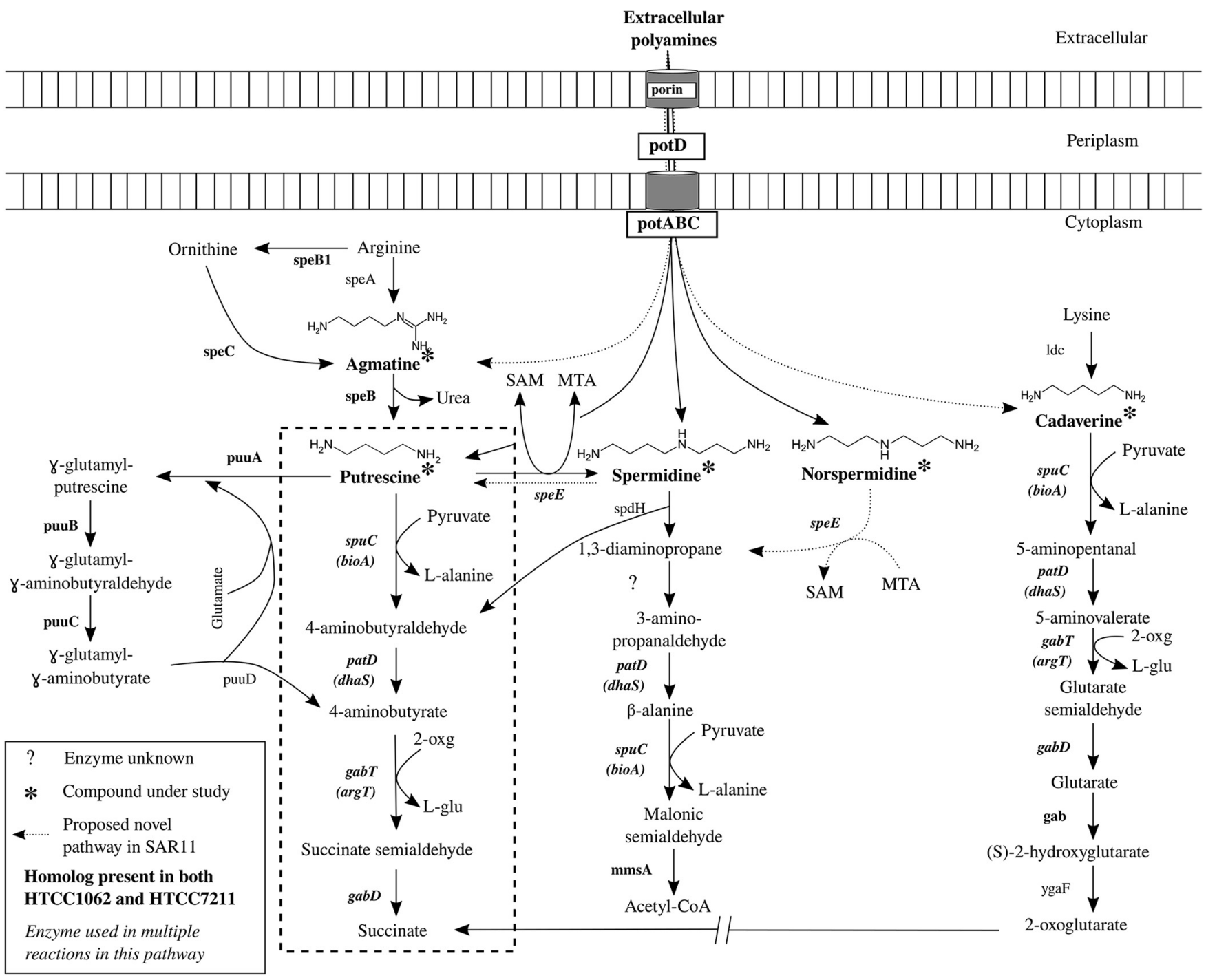

FIG 1 Polyamine compound metabolism in SAR11. Common pathways for polyamine metabolism in bacteria are shown. The compounds under study are marked with asterisks, with enzymes listed in bold if both strains of SAR11 in this study, HTCC1062 and HTCC7211, have homologs to the enzyme, or in plain text if in neither. A question mark indicates that the enzyme is unknown. The enzyme name is in italics if it is used for multiple reactions in this metabolic system. The dashed box encompasses the pathway thought to be used by SAR11 cells for PUT metabolism based on previous studies. Byproducts of reactions where $\mathrm{NH}_{3}$ groups are transferred are included to show the flow of N. Gene names for SAR11 homologs, where different from canonical gene names are listed below the canonical name in parentheses. pot $C$, spermidine/putrescine $A B C$ transporter, permease; pot $B$, permease; pot $D$, SBP; potA, ATP-binding protein; speB1, arginase; speC, lysine/ornithine decarboxylase; speB, agmatinase; speE, spermidine/spermine synthase; puuA, gammaglutamylputrescine synthetase; $p u u B$, gamma-glutamylputrescine oxidoreductase; puuC, NADP/NAD-dependent aldehyde dehydrogenase; puuD, gammaglutamyl-gamma-aminobutyrate hydrolase; spuC, putrescine-pyruvate aminotransferase; pat , 4-aminobutyraldehyde dehydrogenase; gabT, acetylornithine aminotransferase; $g a b D$, succinate-semialdehyde dehydrogenase; $s p d H$, spermidine dehydrogenase; $m m s A$, malonate-semialdehyde dehydrogenase; gab, glutarate 2-hydroxylase; ygaF, L-2-hydroxyglutarate dehydrogenase. SAM; S-adenosylmethionine; MTA, 5'-methylthioadenosine; 2-oxg, 2-oxoglutarate; L-glu, L-glutamate.

use polyamines as $\mathrm{N}$ sources and that polyamines might be substitutes for their conditional auxotrophic requirement of pyruvate $(28,33)$.

\section{RESULTS}

Footprinting and fingerprinting experiments. We focused on five polyamine compounds (Table 1), putrescine (PUT), cadaverine (CAD), agmatine (AGM), norspermidine (NSD), and spermidine (SPD). These compounds were picked either for their prevalence in the environment and in bacterial cells or for their role as precursors to other polyamine compounds $(4,6,34,35)$. These compounds also showed the best recovery in solid-phase extraction and were amenable to simultaneous quantification by LC-MS/MS. We used polyamine concentrations of 10 - to 100 -fold ambient environmental concentrations, 
TABLE 1 List of compounds used in the project as well as LC-MS/MS parameters ${ }^{a}$

\begin{tabular}{|c|c|c|c|c|c|}
\hline Compound (abbreviation) & Structure & Mol wt $(\mathrm{g} / \mathrm{mol})$ & Retention time (min) & MRM parent product $m / z^{b}$ & LOD (nM) \\
\hline 1,3-Diamino-propane (DAP) & $\mathrm{H}_{2} \mathrm{~N}$ & 74.1 & 1.90 & $75.1-58.1$ & 4.51 \\
\hline Putrescine (PUT) & & 88.2 & 1.92 & $89.1-72$ & 2.29 \\
\hline Cadaverine (CAD) & $\mathrm{H}_{2} \mathrm{~N}^{-}$ & 102.2 & 1.95 & $103.1-69,86$ & 1.29 \\
\hline Agmatine (AGM) & & 130.2 & 2.01 & $131.2-72,60$ & 1.85 \\
\hline Norspermidine (NSD) & & 131.2 & 1.74 & $132.2-115,98$ & 2.06 \\
\hline Spermidine (SPD) & & 145.3 & 1.75 & $146.1-112.1,72$ & 1.25 \\
\hline${ }^{13} \mathrm{C}$-spermidine (IS) & & 149.2 & 1.78 & $150.2-116.1,76.1$ & \\
\hline Homospermidine (HSD) & & 159.3 & 1.71 & $160.2-126.0,83.8$ & 5.58 \\
\hline
\end{tabular}

\footnotetext{
${ }^{a}$ The instrumental limit of detection (LOD) for the LC-MS/MS was calculated as three times the standard deviation of the lowest detectable concentration of standards used $(5 \mathrm{nM})$. The actual LOD of samples varied based on how much the samples were concentrated but was generally 2 to 1,000 -fold lower than the instrumental LOD. A collision energy of $20 \mathrm{eV}$ was used for all analytes except 1,3-diaminopropane, which had a CE of $10 \mathrm{eV}$, and homospermidine, which had a CE of $30 \mathrm{eV}$.

${ }^{b}$ The first listed product $\mathrm{m} / \mathrm{z}$ was used for quantification; the second was used for verification. In cases where no second product is listed, the other products were too small for accurate identification.
}

similar to what would be found in nutrient patches (36), as has been done previously (20, 28). In preliminary experiments, we found that high polyamine concentrations inhibited growth; HTCC1062 growth was inhibited when all polyamines were added together at individual concentrations above $500 \mathrm{nM}$, while HTCC7211 growth was inhibited at concentrations above $250 \mathrm{nM}$. We chose $500 \mathrm{nM}$ for HTCC1062 and $250 \mathrm{nM}$ for HTCC7211, the highest concentrations that did not significantly inhibit growth, for further experiments (Fig. S1A and B).

The five polyamines were added to SAR11 cultures under nutrient-replete conditions to measure uptake and metabolism of these compounds. Cultures were grown to late exponential phase before harvesting; growth rates were slightly lower with polyamines added-0.44 compared to 0.46 day $^{-1}$ for HTCC1062 and 0.50 compared to 0.60 day $^{-1}$ for HTCC7211 with and without polyamines (Fig. S2C and D). For both strains, the average intracellular levels of all five polyamine compounds were significantly greater in the experimental treatment (polyamines added) than in the negative control (no polyamines added), except for SPD in HTCC1062, which had nonsignificantly higher levels in experimental cultures (Fig. 2A and C; $P$ values in Table 2). When the intracellular levels are converted to intracellular concentrations using a cell volume of $0.03 \mu \mathrm{m}^{3}$ for HTCC1062 (16) and $0.04 \mu \mathrm{m}^{3}$ for HTCC7211 (37), it is apparent that the cells are concentrating all compounds into intracellular concentrations greater than their environment (Table 2). The intracellular concentrations in the experimental treatment for HTCC7211 were much higher than those in HTCC1062, especially SPD, which was 40 times higher. 


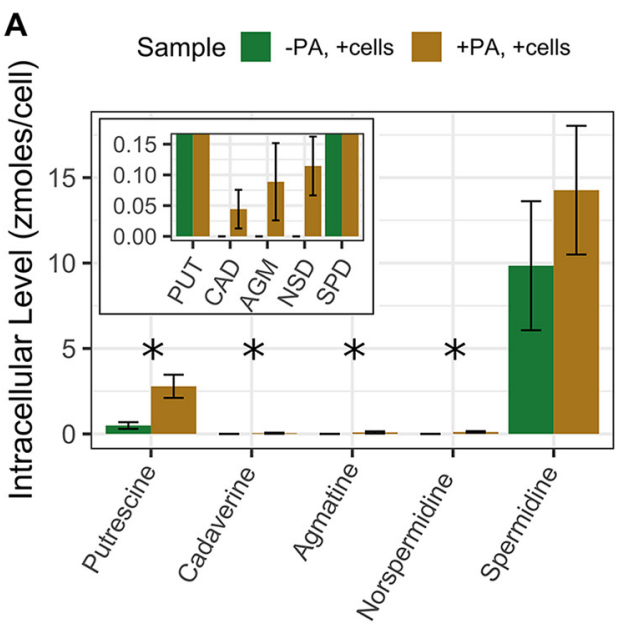

Compound

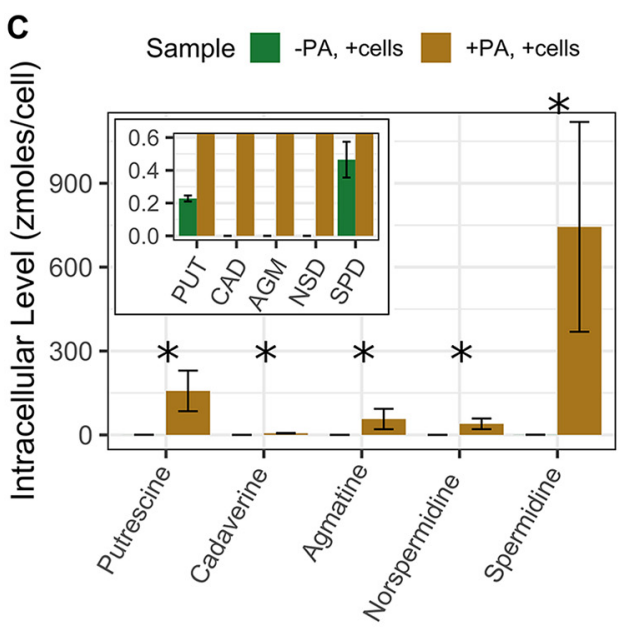

Compound

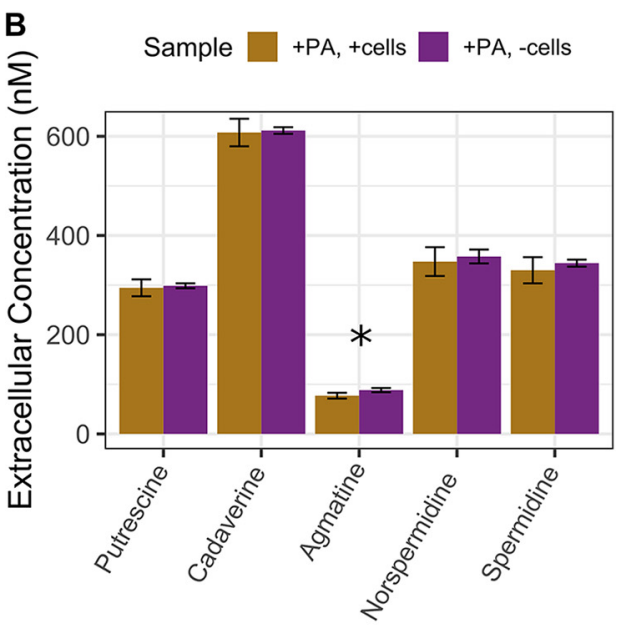

Compound

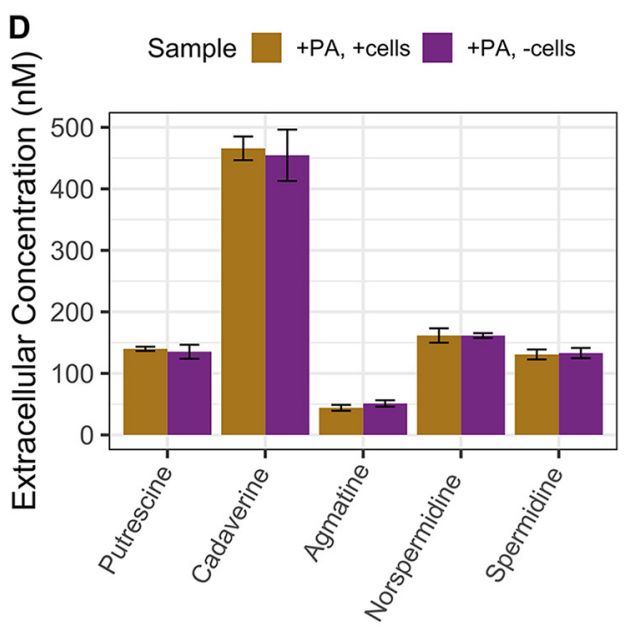

Compound

FIG 2 (A to D) Results of footprinting/fingerprinting experiments with (A and B) "Ca. Pelagibacter ubique" HTCC1062 and (C and D) "Ca. Pelagibacter" strain HTCC7211 with five polyamine compounds. (A and C) Intracellular concentrations of polyamine compounds in cultures with no polyamines added or with a $500 \mathrm{nM}$ or $250 \mathrm{nM}$ final concentration of each polyamine compound added for HTCC1062 or HTCC7211, respectively. (B and D) Extracellular concentrations of polyamine compounds in cultures with a $500 \mathrm{nM}$ or $250 \mathrm{nM}$ final concentration of each polyamine compound added for HTCC1062 or HTCC7211, respectively. The insets in panels A and C show compounds that had very low levels. Error bars are the standard deviations of quadruplicate cultures. * indicates a significant difference $(P<0.05$, one-tailed $t$ test) between the two treatments; for panels $A$ and $C$, it indicates a significantly higher level of that compound in the experimental treatment compared to the negative control; for panels $B$ and $D$, it indicates a significantly lower concentration of that compound in the experimental treatment compared to the no-cells control; for $P$ values, see Table 2 .

In the extracellular fractions of both strains, there were no significant differences between the experimental treatment and the no-cell control (polyamines added, no cells), except for AGM in HTCC1062 (P value of 0.04, one-sided $t$ test) (Fig. 2B and D). In HTCC1062, all five compounds were lower in concentration in the experimental

TABLE 2 Intracellular concentrations of polyamine compounds in SAR11 fingerprinting experiments (see Fig. 2)a

\begin{tabular}{|c|c|c|c|c|c|c|}
\hline \multirow[b]{2}{*}{ Compound } & \multicolumn{3}{|c|}{ HTCC1062 intracellular concn $(\mu \mathrm{M})$} & \multicolumn{3}{|c|}{ HTCC7211 intracellular concn $(\mu \mathrm{M})$} \\
\hline & Neg. Control & +Polyamines & $P$ value & Neg. Control & + Polyamines & $P$ value \\
\hline Putrescine & $16 \pm 6.7$ & $93 \pm 23$ & 0.003 & $6 \pm 0.3$ & $4,030 \pm 1,860$ & 0.03 \\
\hline Cadaverine & 0 & $1.5 \pm 1$ & 0.03 & 0 & $153 \pm 31$ & 0.0002 \\
\hline Agmatine & 0 & $3 \pm 2.1$ & 0.03 & 0 & $1,460 \pm 940$ & 0.02 \\
\hline Nor-spermidine & 0 & $3.8 \pm 1.6$ & 0.01 & 0 & $1,020 \pm 490$ & 0.003 \\
\hline Spermidine & $328 \pm 127$ & $480 \pm 130$ & 0.19 & $12 \pm 2.7$ & $19,100 \pm 9,630$ & 0.01 \\
\hline
\end{tabular}

${ }^{a}$ Concentrations were calculated using cell volumes of 0.03 and $0.04 \mu \mathrm{m}^{3}$ for HTCC1062 and HTCC7211, respectively. The listed $P$ values are for a one-sided $t$ test comparing the + polyamine treatment to the negative-control treatment. 

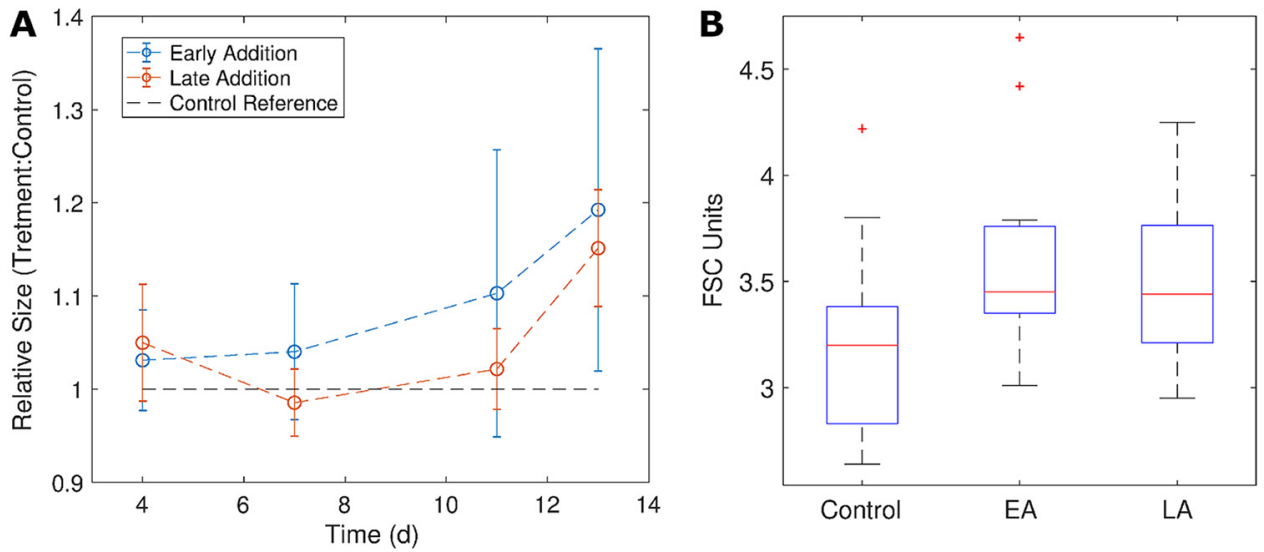

FIG 3 Changes in cell size in "Candidatus Pelagibacter" strain HTCC7211, approximated by forward scatter (FSC), were monitored using flow cytometry in response to the addition of $250 \mathrm{nM}$ polyamines either at the beginning of the experiment (early addition) or after 4 days of growth (late addition). The first measured time point was $4 \mathrm{~h}$ after polyamines were added to the late addition cultures. (A) Mean FSC of the population at each time point from experimental treatments after normalization to the mean of the control treatment cultures (no polyamines added). Error bars are the standard deviation of quadruplicate replicates. (B) Boxplots of the mean FSC values for all time points of the three treatments. The red line is the median value, and the bottom and top edges of the box indicate the 25th and 75th percentiles. Statistical outliers (red + ) are more than 1.5 times the interquartile range away from the bottom or top of the box.

treatment than in the no-cell control (Fig. 2B). For HTCC7211, all five compounds were at similar concentrations between the two treatments, except for AGM, which was lower in the experimental treatment ( $P$ value of 0.06 , one-sided $t$ test).

Flow cytometry experiment. Based on the very high intracellular polyamine concentrations measured in HTCC7211 cells in experimental treatments, we postulated that cells would change in size to accommodate the influx of polyamines. To test this, we used flow cytometry to monitor the forward scatter (FSC), a proxy for cell size, of nutrient-replete HTCC7211 cultures exposed to either no polyamines (control) or 250 $\mathrm{nM}$ each polyamine added at the beginning of growth (early addition) or after 4 days of growth (late addition). On average, both experimental treatments had higher FSC than the control (Fig. 3B). The mean FSC of the early addition cultures was consistently higher than that of the control across all measured time points (Fig. 3B). The mean FSC of the late addition cultures was similar to that of the early addition cultures $4 \mathrm{~h}$ after addition of polyamines to late addition cultures; it then decreased to control levels at day 7, finally increasing above the control level after day 11 (Fig. 3A).

Carbon substitution experiments. Growth experiments were used to examine whether the five polyamine compounds could substitute for two unusual growth requirements of SAR11 cells-pyruvate, or related compounds which lead to a branch of SAR11 metabolism that includes the biosynthesis of alanine, and glycine or related compounds, required for another branch of SAR11 metabolism that includes glycine synthesis. The five polyamine compounds were added together at final concentrations of $250 \mathrm{nM}$ each as a replacement for either pyruvate or glycine, and the growth of the cultures was compared to that of the negative-control treatments with either no pyruvate or no glycine added. With both strains, experimental treatments with added polyamines achieved higher maximum cell densities and higher growth rates than negative controls, but the differences were not significant, indicating that these compounds did not fully substitute for glycine or pyruvate (Table 3 ).

Nitrogen substitution growth experiments. Additional growth experiments were used to determine if polyamine compounds could serve as nitrogen $(\mathrm{N})$ sources. To eliminate organic sources of $\mathrm{N}$ in the media, glycine (required by SAR11 cells) and methionine (required as a sulfur source) were replaced with oxaloacetate and dimethylsulfoniopropionate (DMSP) in a modified artificial seawater medium (27). These substitutions resulted in $\sim 100$-fold lower maximum cell densities due to oxaloacetate being a 
TABLE 3 Growth rates and maximum cell densities for growth experiments with SAR11 cultures to determine if polyamines could substitute for pyruvate or glycine in their growth ${ }^{a}$

\begin{tabular}{|c|c|c|c|c|c|c|}
\hline SAR11 strain & Treatment & $\begin{array}{l}\text { Polyamines } \\
\text { added? }\end{array}$ & Pyruvate added? & Glycine added? & Growth rate $\left(\right.$ day $\left.^{-1}\right) \pm S D$ & $\begin{array}{l}\text { Max. cell density } \\
\text { (cells/ml) } \pm \text { SD }\end{array}$ \\
\hline \multirow[t]{4}{*}{ HTCC1062 } & Positive control & No & Yes & Yes & $0.33 \pm 0.02$ & $3.27 \mathrm{E} 7 \pm 5.72 \mathrm{E} 6$ \\
\hline & Negative control & No & Yes & No & $0.21 \pm 0.003$ & $4.19 \mathrm{E} 6 \pm 7.63 \mathrm{E} 5$ \\
\hline & Negative control & No & No & Yes & $0.14 \pm 0.03$ & $1.25 \mathrm{E} 6 \pm 4.65 \mathrm{E} 5$ \\
\hline & Exptl & Yes & No & Yes & $0.15 \pm 0.01$ & $1.36 \mathrm{E} 6 \pm 2.22 \mathrm{E} 5$ \\
\hline \multirow{3}{*}{ HTCC7211 } & Exptl & Yes & Yes & No & $-0.12 \pm 0.1$ & $7.57 \mathrm{E} 4 \pm 2.37 \mathrm{E} 4$ \\
\hline & Negative control & No & No & Yes & $0.19 \pm 0.02$ & $1.04 \mathrm{E} 6 \pm 2.55 \mathrm{E} 5$ \\
\hline & Exptl & Yes & No & Yes & $0.22 \pm 0.03$ & $1.76 \mathrm{E} 6 \pm 3.41 \mathrm{E} 5$ \\
\hline
\end{tabular}

${ }^{a}$ All five polyamine compounds were added at a $250 \mathrm{nM}$ final concentration each in place of either pyruvate or glycine and compared to negative controls with either no pyruvate or glycine added. Pyruvate was added at $100 \mu \mathrm{M}$ and glycine at $50 \mu \mathrm{M} ; 10 \mu \mathrm{M}$ methionine and vitamins were added to all cultures in artificial seawater medium (see Materials and Methods).

weak glycine substitute. The five polyamine compounds were added to SAR11 cultures grown in the modified artificial seawater (ASW) medium either all together at a final concentration of $150 \mathrm{nM}$ for each compound, or individually at concentrations that provided equivalent amounts of $\mathrm{N}(245 \mathrm{nM} \mathrm{N})$. Maximum cell densities were compared to a negative control with no added $\mathrm{N}(-\mathrm{C},-\mathrm{N})$, a positive control with excess $\mathrm{N}$ in the form of ammonium sulfate $(+\mathrm{C}$, excess $\mathrm{N})$, and a positive control with equimolar $\mathrm{N}$ in the form of ammonium sulfate ( $+C$, equimolar N) (Fig. 4).

For HTCC1062, addition of two compounds, CAD and SPD, resulted in significantly higher maximum cell densities than the equimolar positive control (maximum cell densities and $P$ values in Table S2) (Fig. 4). Addition of NSD, PUT, and all polyamines combined resulted in higher, albeit nonsignificant, maximum cell densities than for the equimolar positive control. Only addition of SPD resulted in a higher cell density than the negative control, but the difference was not significant. For HTCC7211, addition of SPD resulted in a significantly higher maximum cell density than those in all three controls. Cultures to which CAD was added had significantly higher maximum cell densities than the equimolar control and the negative control. Cultures with PUT added had a significantly higher maximum cell density than only the equimolar control. In both strains, the addition of AGM resulted in lower maximum cell densities than those of any control treatments; in HTCC7211, the treatments with NSD and with all polyamines combined also had lower maximum cell densities than those of any controls. Interestingly, diauxic growth was observed in HTCC1062, with an early peak around 14 days and a larger peak later around 40 days (Fig. 4), which was not observed in HTCC7211.

Metabolic pathways. Figure 1 shows genes for polyamine metabolism for the two SAR1 1 strains used in this study, overlaid on common pathways for polyamine metabolism $(8,12,33,38-40)$. In both strains, AGM is postulated to be converted by agmatinase (speB) to PUT, which is catabolized by the transamination pathway, since neither strain encodes the final enzyme in the $\gamma$-glutamylation pathway, and the transamination pathway was upregulated in SAR11 cells in response to PUT addition (28). CAD is likely metabolized to succinate via the lysine degradation pathway. Many genes involved in polyamine metabolism are known to be multifunctional (in terms of broad catalytic/substrate range) in other cell types $(33,41)$, as we also predict in SAR11 (Fig. 1; Fig. S2).

In metabolic reconstruction from genome sequences (42), we found that neither SAR1 1 strain encoded a clear pathway of SPD or NSD metabolism, although both compounds were taken up from the medium and metabolized (Fig. 2 and 4). In our analysis of genomes, we found that both strains lack the genes present in several Vibrio strains (43) that are responsible for producing and metabolizing NSD via carboxynorspermidine. Furthermore, we found that neither SAR11 strain has homologs for the canonical 

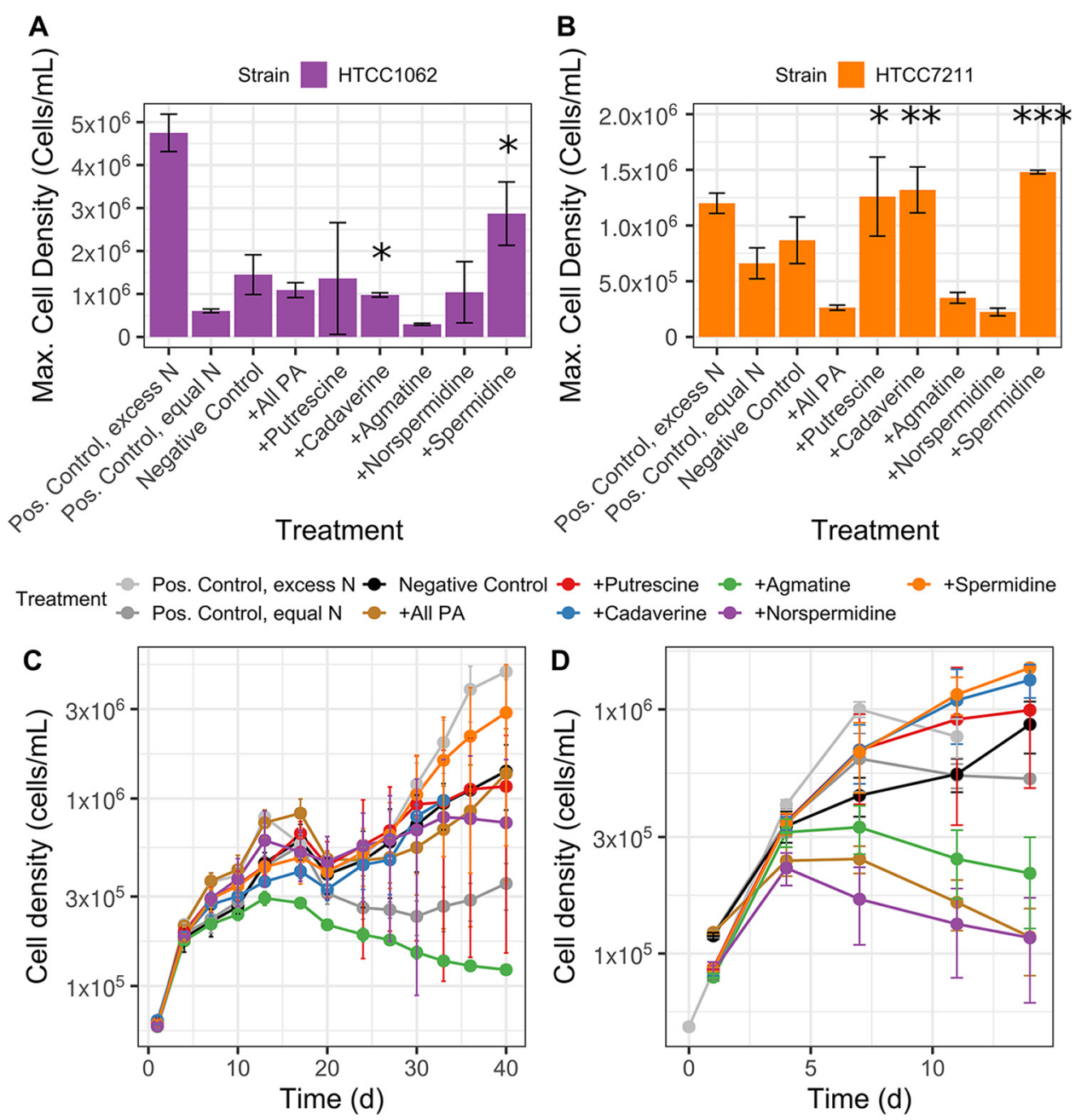

FIG 4 Several polyamine compounds are used by SAR11 cells as a nitrogen (N) source, as indicated by higher maximum cell densities ( $A$ and $B$ ) during growth experiments compared to control cultures. (C and D) Growth curves of cultures, from which the maximum cell densities were calculated. SAR11 cells, either HTCC1062 (A and C) or HTCC7211 (B and D) were grown on a modified ASM recipe (see Materials and Methods) without any $\mathrm{N}$ source. Negative-control cultures had no $\mathrm{N}$ added. Positive-control cultures were grown with $\mathrm{N}$ in the form of $\left(\mathrm{NH}_{4}\right)_{2} \mathrm{SO}$, with either $400 \mu \mathrm{M}$ (pos. control, excess $\mathrm{N}$ ) or with equimolar $\mathrm{N}$ equal to the amount of $\mathrm{N}$ $(245 \mathrm{nM} \mathrm{N})$ added in the polyamine treatments (pos. control, equal N). Experimental treatments had equal amounts of $\mathrm{N}(245 \mathrm{nM} \mathrm{N})$ added in the form of either all five polyamine compounds together, the final concentration of $150 \mathrm{nM}$ for each compound (+all polyamines), or with individual polyamine compounds. Cultures were started from cultures that had been grown to the late exponential phase on the same media without any N, to eliminate any carryover from previous growth. Error bars represent the standard deviation of triplicate samples. *, significantly higher maximum cell density compared to the pos. control, equal $\mathrm{N}$ treatment (one-sided $t$ test, $P<0.05$ ); ${ }^{* *}$, significantly higher maximum cell density compared to both pos. control, equal $\mathrm{N}$ and negative-control treatments (one-sided $t$ test, $P<0.05$ ); ${ }^{* * *}$, significantly higher maximum cell density compared to all three control treatments (one-sided $t$ test, $P<0.05$ ). For HTCC7211, results from two separate experiments are shown together.

genes responsible for SPD metabolism—SPD dehydrogenase (spdH), which cleaves SPD to produce 1,3-diaminopropane (DAP) and 4-aminobutanal, and SPD acetyltransferase, which converts SPD to acetylspermidine, a less toxic version of SPD. To explain the uptake and metabolism of SPD and NSD despite the lack of canonical metabolic genes for these compounds, we hypothesized that either the SPD synthase enzyme, SpeE, is bi-directional, producing PUT from SPD, or there is another, unknown enzyme capable of cleaving SPD. SpeE is not known to be bi-directional in other bacteria (44, 45). A possible candidate enzyme for SPD metabolism was discovered in both strains of SAR11 during metabolic reconstruction, dys2, a putative deoxyhypusine synthase (dhs) gene (Fig. S2). In other bacteria, the enzyme produced by dhs usually acts as a 


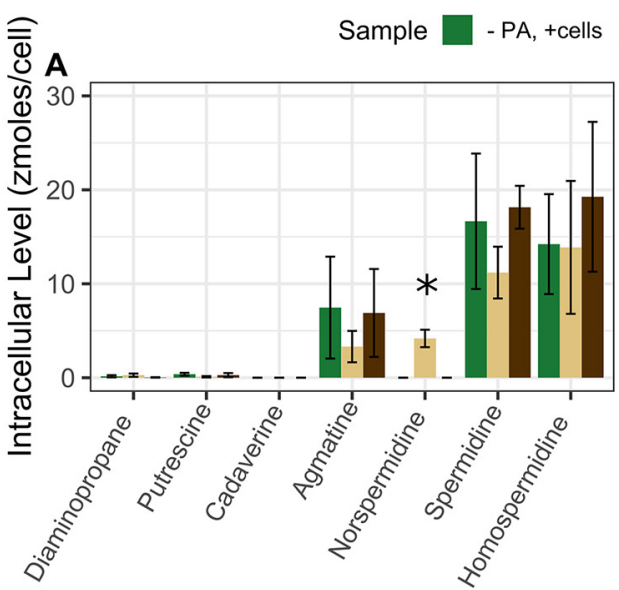

Compound

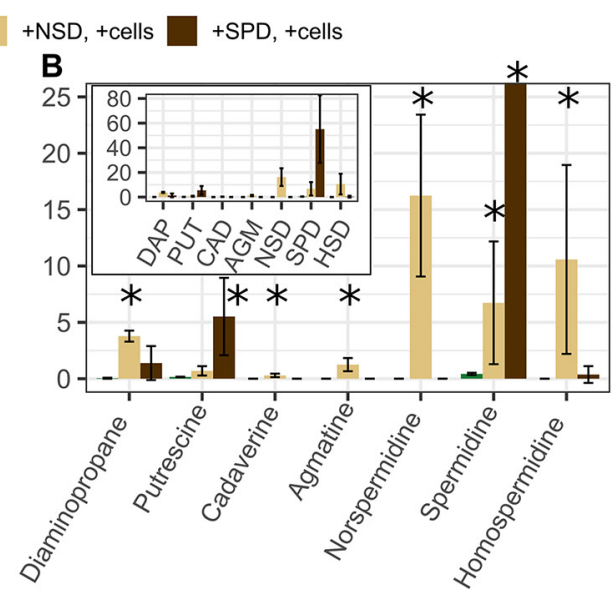

Compound

FIG 5 (A and B) Intracellular polyamine levels indicating pathways for norspermidine (NSD) and spermidine (SPD) metabolism in (A) HTCC1062 and (B) HTCC7211. Cultures were grown in nutrient-replete conditions either without any added polyamines, with $500 \mathrm{nM}$ NSD, or with $500 \mathrm{nM} \mathrm{SPD}$ added. Cells were harvested at the late exponential phase, and intracellular polyamines were extracted as described in Materials and Methods. * indicates a significantly higher level of that compound compared to the control treatment with no polyamines added (one-sided $t$ test, $P<0.05$ ). Error bars are the standard deviation of quadruplicate cultures.

homospermidine (HSD) synthase, a promiscuous enzyme capable of acting on multiple polyamines in addition to its native function of producing HSD from PUT (46-48).

To test our hypothesis and differentiate between these two alternative routes of SPD metabolism and identify pathways of NSD metabolism in SAR11, we used fingerprinting to search for possible by-products of SPD and NSD metabolism, including DAP and HSD. If SAR11 cells use the reverse SPD synthase reaction to metabolize SPD, the products would be PUT and S-adenosylmethionine, while the by-products of the Dys2 enzyme, if it is an HSD synthase, would primarily be HSD and DAP. We compared polyamine levels in SAR11 cells grown either without any polyamines or with either $500 \mathrm{nM}$ SPD or NSD (Fig. 5). As expected, in both strains, the treatments with SPD or NSD added had higher levels of that compound in the respective treatment (one-sided $t$ test, $P$ values of 0.02 and 0.003 for + SPD and + NSD versus the negative control, respectively; $P$ values were 0.06 and 0.2 for HTCC1062), indicating an uptake of those two compounds by both strains.

In HTCC7211, the +SPD cultures also had significantly higher levels of PUT than the negative control (one-sided $t$ test, $P$ value of 0.05 ) but only a slight, nonsignificant increase in DAP (Fig. 5B). In the +NSD cultures, there were significantly higher levels of DAP than in the negative control (one-sided $t$ test, $P$ value of 0.001 ). There was also a significant increase in SPD and HSD (one-sided $t$ test, $P$ values of 0.05 and 0.04 ) in +NSD cultures compared to the negative control. In HTCC1062, there were no differences in the levels of any other compounds in the +NSD or + SPD treatments compared to those of the negative control, aside from SPD and NSD themselves and a nonsignificant increase in DAP in the +NSD treatment (Fig. 5A). The increase in DAP in HTCC7211 in both the +SPD and + NSD cultures and low levels of HSD in these treatments lend support to SpeE being responsible for SPD and NSD metabolism.

\section{DISCUSSION}

SAR11 cells devote much of their cellular structure and energy to transport functions to compete for resources in the world's nutrient-limited oceans $(17,18,20)$. One of the primary transporters expressed by SAR 11 cells, PotABCD, transports polyamines, yet little is known about the types and amounts of polyamines used by SAR11, the role of polyamines in SAR11 growth, and the pathways used by SAR11 for polyamine metabolism. Here, we show that SAR11 cells took up and metabolized all five polyamine 
compounds tested and concentrated polyamines to $\mu \mathrm{M}$ and even $\mathrm{mM}$ intracellular concentrations. Cells increased in size while concentrating polyamines, probably as a consequence of osmosis and increasing turgor pressure inside the cells. We also show that SAR1 1 cells primarily use polyamines as a N source and propose metabolic pathways for SPD and NSD, two compounds for which catabolic pathways in marine bacteria are uncertain.

The growth of SAR11 cultures was found to be inhibited by high polyamine concentrations (Fig. S1; Fig. 3). Polyamines are known to be toxic to bacteria when added to media at high concentrations (generally $\mathrm{mM}$ range), but the mechanism is not known $(40,49,50)$. SAR1 1 cells often lack transcriptional regulation for carbon oxidation functions (15), and previous work indicated they do not upregulate metabolic enzymes for polyamines when $\mathrm{N}$ limited (27). The growth inhibition observed at high polyamine concentrations might be due to adverse effects of the buildup of polyamine compounds inside the cells. Similar results previously have been observed in cells experiencing metabolic pathway saturation (51). Intracellular concentrations of polyamines were higher in HTCC7211 than in HTCC1062, and HTCC7211 was also more susceptible to growth inhibition by polyamines, indicating that the buildup of polyamines inside the cells might be linked to growth inhibition (Fig. S1A and B; Table 2).

Uptake of polyamine compounds by SAR11 cells. Organisms produce intracellular polyamines for a variety of cellular processes, including stabilization of DNA, RNA, and proteins (3). The native polyamines produced by these strains (SPD and HSD in HTCC1062 and SPD alone in HTCC7211 [Fig. 2 and 5]) are consistent with past reports that alphaproteobacteria primarily make PUT, SPD, or HSD as polyamines (52). AGM and PUT, intermediates in the synthesis of SPD and HSD (Fig. 1), were also detected at low levels. The concentrations of native polyamines measured in SAR11 cells are similar to those measured in various phytoplankton (4) but $\sim 10$-fold lower than those found in other alphaproteobacteria (52).

Both strains took up all five polyamines in excess of metabolic rates, causing higher (10- to 1,000-fold higher) intracellular concentrations in experimental treatments relative to negative controls (Fig. $2 \mathrm{~A}$ and C). Intracellular levels were in the zeptomole $\left(10^{-21} \mathrm{~mol}\right.$, or $1^{3}$ molecules $) / c e l l$ range, similar to levels measured before in SAR11 cells for metabolites such as glycine betaine and $\operatorname{DMSP}(20,53)$. Intracellular polyamines reached $\mu \mathrm{M}$ concentrations in HTCC1062 and mM concentrations in HTCC7211, $20 \mathrm{mM}$ in the case of SPD in HTCC7211 (Table 2). The polyamine concentrations taken up by HTCC1062, although in the low $\mu \mathrm{M}$ range for some compounds, are likely still high enough to be used effectively in metabolism, given the low $\mu \mathrm{M} K_{m}$ values measured for enzymes involved in polyamine metabolism in other cells $(44,54-57)$. In response to the large influx of polyamine compounds, HTCC7211 cells increased in size within hours, as indicated by the high level of FSC in the late addition treatment cultures compared to that of the negative-control treatment cultures at the first measured time point, taken $4 \mathrm{~h}$ after polyamines were added, with cell size increasing the most after several days of exposure (Fig. 3).

Substrate uptake in excess of metabolic rate has been observed previously in SAR11 cells with the osmolyte dimethylsulfoniopropionate (DMSP) (53). A parallel phenomenon, termed "luxury uptake," has been described in phytoplankton that take up phosphorous and nitrogen in excess of their requirements and store them in organic forms for later use $(58,59)$. However, the excess substrate uptake we observed does not fit the canonical definition of luxury uptake, since the amount of $\mathrm{N}$ from the stored polyamines in SAR11 cells was far less than their requirement for a cell division; concentrated polyamines inside SAR11 cells in the experimental treatment made up only $0.005 \%$ for HTCC 1062 and $0.27 \%$ for HTCC7211 of the cellular N quota, estimated at $0.11 \mathrm{fmol} \mathrm{N} /$ cell (37).

Theoretically, excess uptake such as what we observed enhances the ability of cells to exploit nutrient patches, giving them a cache of nutrients to process subsequently after exiting a nutrient patch. Moreover, given that SAR11 cells are by far the most 
abundant cell type in the ocean, luxury uptake by SAR11 cells could be a populationlevel strategy that lowers ambient nutrient concentrations to levels where SAR11 cells are more competitive for transport, effectively taking nutrients off the table. Past theoretical work has shown that superior competitors in patchy environments lower average nutrient concentrations (60). Our findings may stimulate further research aimed at understanding whether these cellular behaviors apply to other substrate compounds used by SAR11 cells, whether similar behavior is exhibited by other oligotrophs, and whether the imbalance between transport and metabolism we observed occurs in natural populations and plays an adaptive role by allowing transient storage of exometabolites inside cells.

Although HTCC1062 and HTCC7211 transported all five compounds from the media, there were few observable depletions of extracellular concentrations for any polyamines with either strain because the intracellular polyamine pools were small relative to the surrounding volume (Fig. $2 \mathrm{C}$ and D). The observed accumulation of intracellular polyamines was estimated to result in pmolar drawdowns of the dissolved polyamine pool, which in most cases was less than the precision of our measurements (Table S3). An exception was the accumulation of $239 \mathrm{pmol}$ of intracellular SPD in HTCC7211, which should have produced a measurable depletion of SPD in the medium, yet no significant reduction was observed (standard deviation of $83.3 \mathrm{pmol}$ ). This observation suggests that HTCC7211 cells used other transported polyamines to synthesize SPD. To support this interpretation, HTCC7211 cells given only SPD had 10-fold lower SPD levels than when given all five compounds (compare Fig. $2 \mathrm{C}$ and Fig. 5B). It appears that transported polyamines are converted intracellularly to SPD, which then accumulates in HTCC7211.

Our analysis suggests the PotABCD transport system in SAR11 is responsible for transporting the five polyamines we tested, given the structural similarity between these compounds and the absence of other candidates for polyamine transport functions. However, this remains to be experimentally validated, as was done previously for the glycine betaine transporter in SAR11, which was found to transport seven different substrates (20). Both strains of SAR11 lack homologs for CAD, NSD, or AGM transporters found in other bacteria. In Vibrio cholerae, NSD is transported by a potABCD homo$\log$ (61), but CAD and AGM have not previously been identified as substrates for potABCD. In Escherichia coli, PotABCD is primarily a PUT/SPD/SPM transporter (62), which could help explain the higher accumulation of these compounds in SAR11 cells, even when accounting for native PUT and SPD production. It is likely that other ABC transporters in SAR11 cells are also multifunctional (e.g., able to transport a wider range of substrates than canonically), given the use of a wide variety of amino acids and carboxylic acids by SAR11 cells (63-65).

Interestingly, there was a large difference between the two SAR11 strains in the amounts of polyamines taken up. Polyamine concentrations in HTCC7211 were 40- to 500-fold higher than those of HTCC1062, despite HTCC7211 being exposed to 2-fold lower concentrations of polyamines. This difference cannot be explained entirely by cell size; HTCC7211 cells are only $\sim 1.3$-fold larger, as measured by C content, than HTCC1062 cells (37). The differential could be because the HTCC7211 transport system has a higher $V_{\max }$ for polyamine transport than HTCC1062, due either to the properties of the proteins themselves (one of the two permease proteins involved in polyamine transport, PotB, is only $82 \%$ identical), differing abundances of transport proteins, or the cytoarchitecture of the cells. There were no major differences between the two strains in the presence/absence of polyamine metabolic genes, nor in the location of those genes (Fig. S2). One possible ecological explanation for the difference between these two strains, if they are typical of the ecotypes they represent, is that HTCC1062, a member of the primarily coastal subclade of SAR11, may have been influenced by selection that limits toxic buildups of polyamines at the higher polyamine concentrations found in coastal regions. HTCC7211, a member of a primarily open ocean subclade of 
SAR11, would rarely experience the high polyamine concentrations found in coastal regions and so might not experience selection to limit intracellular buildups.

Use of polyamines by SAR11 cells. SAR11 cells have unique growth requirements, needing a reduced sulfur source (e.g., methionine or methane thiol), a glycine source, specific vitamins, and a carbon source that can serve as a precursor to alanine (usually pyruvate) (64). Most of the tested polyamine compounds are predicted to be metabolized to succinate, a tricarboxylic acid (TCA) cycle intermediate (Fig. 1). In previous work, succinate did not substitute for pyruvate in HTCC1062, in accord with our experimental findings (66). This does not rule out the use of polyamines as an energy source, however. Other small compounds have been found previously to be used by SAR11 cells only as an energy source and not as a pyruvate substitute $(20,65)$. Polyamines are also required for a variety of other cellular processes, and it is likely that SAR11 cells used the supplied polyamines in those processes in addition to metabolizing them.

Both strains of SAR11 tested could use several polyamine compounds (SPD, CAD, and PUT) as a N source, with SPD supporting the highest maximum cell density of any of the polyamines (Fig. 4A). NSD does not appear to be a N substitute for either strain of SAR11 at the NSD concentration tested, but it is transported (Fig. 5). The use of multiple polyamines as $\mathrm{N}$ sources is consistent with previous reports that SAR11 cells use a variety of organic N-containing compounds as $\mathrm{N}$ sources (27).

Interestingly, two compounds (AGM and NSD) were inhibitory to SAR11 growth under N-limiting conditions (Fig. 4). One potential cause for the AGM inhibition is the by-product of AGM degradation by the agmatinase enzyme, urea. Neither SAR11 strain encodes a urease (67). We speculate that the influx of AGM causes a build-up of inhibitory urea in cells, a process that is known to occur in oligotrophs due to metabolic pathway saturation $(15,51)$. This does not, however, preclude AGM from also being used as a $\mathrm{N}$ source by the cells at environmental AGM concentrations.

Surprisingly, all HTCC1062 cultures, including controls, exhibited diauxic growth during N-substitution experiments, while HTCC7211 cultures, under similar conditions, did not. Diauxic growth is generally observed when cells switch from using one source of nutrients to another. However, the cultures used to start these experiments were acclimated to the same medium (without $\mathrm{N}$ ) prior to the experiment starting. Previously, diauxic growth was observed in HTCC7211 grown on alternate P sources, which was attributed to the switch from using inorganic $P$ to organic $P$ sources (68). Another unexpected observation, found in both strains and across several repetitions, was that the equimolar positive control always had a lower maximum cell density than the negative control with no $\mathrm{N}$ added.

Metabolic pathways for spermidine and norspermidine. SPD metabolism has been observed in marine bacteria without a spermidine dehydrogenase gene (spdH) $(9,11,28)$. It has been speculated that the enzyme that synthesizes SPD from PUT, SpeE, is bi-directional, although this activity was not confirmed experimentally (9), and SpeE is known to not be bi-directional in other cell types $(44,45)$. In HTCC7211, it appears that SPD is primarily metabolized via the reverse SPD synthase reaction, not via the Dys2 enzyme, as no significant increase in HSD was detected, while an increase in PUT was observed (Fig. 5B). The SpeE enzyme in SAR11 previously has been found to be multifunctional, both in terms of being a multidomain protein as the result of a gene fusion event and showing broad substrate range, with high biosynthetic activity on multiple polyamines (69). Our data suggest that this enzyme is multifunctional not only in its substrate range, but also in its ability to carry out catalytic reactions in reverse of its usual biosynthetic activities, which is known to not occur in other cell types (44). The results from HTCC1062 on SPD metabolism are not as clear, as no other differences between the + SPD treatment and the negative control were observed aside from an increase in SPD (Fig. 5A).

We propose that NSD is metabolized in HTCC7211 by the enzyme SpeE, similar to SPD, since we observed increased levels of DAP in the NSD treatment, and the SpeE enzyme in SAR11 has a wide substrate rage (Fig. 5B). With these data, we cannot rule out the Dys2 enzyme metabolizing NSD. In HTCC7211, there was also an increase in 
SPD and HSD in the + NSD treatment (Fig. 5B). The Dys2 enzyme in SAR1 1 cells may be responsible for producing SPD and HSD from the excess NSD and DAP, since dhs homologs in bacteria are known to produce SPD from PUT and DAP, in addition to producing HSD from PUT $(46,47,70)$. It appears that the dys2 gene in both SAR1 1 strains is not primarily acting as an HSD synthase, since there was relatively low production of HSD under any condition, in contrast to other prokaryotes with an HSD synthase gene where HSD is the sole polyamine present $(47,70)$.

We evaluated the hypothesis that SPD synthase might be catalyzing reactions that are the reverse of its ordinary action of synthesizing polyamines. We explored thermodynamic models that predicted the energies of the compounds in the primary reaction catalyzed by SPD synthase (forming SPD from PUT; Fig. S3), without considering entropy terms (Text S1; Table S4). The estimated $\Delta \mathrm{E}$ value for the total reaction was positive $(14.32 \mathrm{kcal} / \mathrm{mol})$ when water was used as the proton acceptor (it is expected that $\Delta \mathrm{H}^{\circ}$ values will be quite similar to $\Delta \mathrm{E}$ values) (Table S5). More favorable acceptors (e.g., imidazole) easily yield negative $\Delta E$ values of $-23.49 \mathrm{kcal} / \mathrm{mol}$ (Table S5). Our findings suggest that the direction of this reaction is easily tunable by including proton carriers of various strengths. This calculation treated each chemical species as an isolated unit and did not take any account of intermolecular interactions. We did not consider the very high intracellular concentrations of polyamines we observed experimentally, which might further drive this reaction in the reverse of its canonical function in polyamine biosynthesis.

Conclusion. Some properties of plankton cells that are important to understanding and modeling their behavior in natural ecosystems can only be measured by experimentation. Recently, we demonstrated very low whole-cell affinities and multifunctionality in the osmolyte transport system of cultured SAR11 cells. We attributed these competitively advantageous cell properties to synergism between kinetic features of the glycine betaine transporter ProXYZ and unusual aspects of SAR11 cell architecture, notably their small size and large periplasm packed with abundant substrate binding proteins (20). Here, we investigate SAR11 metabolism of polyamines, which are transported into cells by the highly abundant SAR11 transporter system PotABCD. We find that this system is also multifunctional and that the two SAR11 strains metabolized a variety of polyamines, which served the cells as $\mathrm{N}$ sources. Our growth experiments did not find that polyamines were able to substitute for glycine (or related compounds) or pyruvate (or related compounds) in their growth. In previous work, we have shown that several C1 compounds are used by SAR11 as energy sources via tetrahydrofolate-mediated oxidation but not as a source of carbon for biomass production (65), which may be the case with polyamines. Our data strongly support the hypothesis that SAR11 uses many polyamines via a simplified system of few enzymes and a single transporter. They mainly use these compounds as an $\mathrm{N}$ source and perhaps to supplement their intracellular polyamine pool, potentially important adaptations in $\mathrm{N}$-limited marine systems.

Polyamine transport rates exceeded metabolic rates, leading to $\mathrm{mM}$ intracellular polyamine accumulations and an increase in cell size over a period of days. We propose that SAR11 cells use the multifunctional enzyme spermidine synthase, SpeE, in reversible reactions that can both produce SPD and catabolize SPD and NSD. The findings we report indicate enzyme multifunctionality expands the range of DOM compounds these cells harvest, which may partially explain how these cells attain high success in competition for DOM resources. Our findings also support previous observations which indicated SAR11 cells concentrate some metabolites during pulses of availability, metabolizing them subsequently (53). In principle, this cell behavior could increase the success of SAR11 cells in competition for nutrient patches, but further experimental work and modeling are needed to evaluate this hypothesis. In any case, the properties of cells that we uncovered here are neither typical nor trivial; they change our understanding of how competition for DOM resources has led to the emergence 
of specialized cell types and will likely inform future experimental research and modeling aimed at understanding cell evolution and the ocean carbon cycle.

\section{MATERIALS AND METHODS}

SAR11 growth and washing. The protocol for SAR11 growth conditions, cell counts, and washing has been previously reported (20). Briefly, "Candidatus Pelagibacter" sp. HTCC7211 and "Ca. Pelagibacter ubique" HTCC1062 were grown in artificial seawater (ASW) amended with $100 \mu \mathrm{M}$ pyruvate, $50 \mu \mathrm{M}$ glycine, $10 \mu \mathrm{M}$ methionine, and SAR11-specific vitamins at either 25 or $16^{\circ} \mathrm{C}$ (HTCC7211 and HTCC1062, respectively) in $12 \mathrm{~h}$ light/dark $(64,66)$. For testing polyamines as a nitrogen $(\mathrm{N})$ source, a modified ASW was used without inorganic $\mathrm{N}$ (ammonium sulfate). This modified ASW was amended with $100 \mu \mathrm{M}$ pyruvate, $50 \mu \mathrm{M}$ oxaloacetate (instead of glycine), $1 \mu \mathrm{M}$ dimethylsulfoniopropionate (DMSP; instead of methionine), and vitamins, since both glycine and methionine provide potential organic $\mathrm{N}$ sources (27).

In the growth experiments testing polyamines as a N source, there were two positive controls, a Nreplete positive control, with $400 \mu \mathrm{M}$ ammonium sulfate added, and an equimolar N-positive control, containing the same stoichiometric ammonium sulfate concentration as the experimental cultures with organic $\mathrm{N}$ sources (polyamines). For growth experiments, cell counts were taken at least twice a week, and growth rates and maximum cell densities were calculated as described previously (64). For growth experiments, a starting cell density of $1 \mathrm{E} 5$ cells $/ \mathrm{ml}$ was used; a density of $5 \mathrm{E} 4 \mathrm{cell} / \mathrm{s} / \mathrm{ml}$ was used in experiments using the modified ASW, as cells grew to a lower maximum cell density in this medium. For the experiments testing polyamines as a $\mathrm{N}$ source, cultures were started from cultures grown without $\mathrm{N}$ to late exponential phase to exhaust any carryover $\mathrm{N}$.

For footprinting/fingerprinting experiments, cells were harvested using centrifugation (BeckmanCoulter $\mathrm{J2}-21$ ) at $10^{\circ} \mathrm{C}$ at $30,000 \times g$ for $90 \mathrm{~min}$. Cell pellets were resuspended in Tris-EDTA (TE) buffer and pelleted again (Beckman-Coulter Ultracentrifuge) at $12^{\circ} \mathrm{C}$ at $48,000 \times g$ for $60 \mathrm{~min}$ (20).

Footprinting and fingerprinting experiments. To measure the identity and quantity of polyamine compounds used by SAR11 cells, a panel of five common polyamine compounds was added to SAR11 cultures at the beginning of growth under normal growth conditions. The polyamine compounds used were putrescine (PUT), cadaverine (CAD), agmatine (AGM), norspermidine (NSD), and spermidine (SPD). Each polyamine compound was added at a final concentration of $500 \mathrm{nM}$ for HTCC1062 or $250 \mathrm{nM}$ for HTCC7211; $250 \mathrm{nM}$ was used for HTCC7211 as they were found to be inhibited in growth at $500 \mathrm{nM}$ (Fig. S1A and B). Concentrations used were about at $100 \times$ ambient polyamine concentrations for several reasons - to allow for accurate quantification of polyamines, to match the high densities of cells used, which were also about $100 \times$ average cell densities in the ocean, and to match previous amendment studies with polyamines and other, similar compounds $(28,30,71)$. A negative-control treatment with SAR11 cells but no polyamines added was used to measure native polyamine production and background polyamine concentrations in the ASW. A no-cell control with polyamines and no SAR11 cells was also included to account for degradation of polyamines, extraction efficiency during SPE, and carryover polyamines in the intracellular measurements. All treatments were done in quadruplicate. Samples were taken for cell counts twice a week; samples for extracellular (footprint) and intracellular (fingerprint) polyamine measurements were taken in the late exponential phase.

The metabolic pathways of two of the polyamine compounds, SPD and NSD, are not clear in SAR11 cells. Thus, further fingerprinting experiments were carried out with SPD and NSD added separately to cultures at $500 \mathrm{nM}$. Several possible metabolic intermediates and by-products were measured in these cells and compared to a negative control with no polyamines added.

Intracellular polyamine extraction. Intracellular polyamines were extracted from SAR11 cells using a method adapted from targeted marine metabolomics studies (72). Cells were pelleted and washed in TE buffer as described above. The supernatant was then completely removed, and the cell pellet was resuspended in $10 \mu \mathrm{l}$ of fresh TE buffer. The volume was determined via an analytical balance. Then, 1 $\mu$ l of resuspended cells was removed and diluted 1:200 in TE buffer to determine cellular abundance for per-cell normalization. Cells were lysed by adding $100 \mu \mathrm{l}$ of cold methanol (MeOH; LC-MS grade) to the cell suspension, followed by the addition of $300 \mu \mathrm{l}$ of cold $1 \mathrm{M}$ acetic acid (72). Cell lysis and polyamine extraction were completed by shaking samples on high for $5 \mathrm{~min}$, followed by rest in ice for $1 \mathrm{~min}$ to avoid overheating, repeated three times. A liquid-phase extraction was used to remove hydrophobic components of the cellular matrix; $400 \mu \mathrm{l}$ of chloroform (LC-MS grade) was added, and the samples shaken for $1 \mathrm{~min}$, followed by centrifugation for $5 \mathrm{~min}$ at $5,000 \mathrm{rpm}$ to achieve phase separation. The aqueous layer containing the polyamines was transferred into a new tube, and the organic layer was discarded. The resulting sample was concentrated via drying under a nitrogen stream at $30^{\circ} \mathrm{C}$. The dried samples were resuspended in $30 \mu \mathrm{l}$ of 50:50 $1 \mathrm{M}$ acetic acid:acetonitrile (73), weighed, and analyzed as described below. When $125 \mathrm{nM}$ standards of each compound were extracted using this method, minimal degradation was observed, with over $60 \%$ recovery (Table S1). Because no intracellular polyamine standard reference exists, the reported intracellular measurements in this paper were not corrected for recovery efficiency.

Extracellular SPE extraction. Polyamines dissolved in the culture media were extracted using a solid-phase extraction (SPE) as described previously (73). A total of $10 \mathrm{ml}$ of the supernatant from the initial centrifugation of cultures (described above) was used for each sample. Polyamines were extracted via gravity alone (nominal flow rate of $0.07 \mathrm{ml} / \mathrm{min}$ ) onto a 1,000- $\mathrm{mg}$ Bond Elut $-\mathrm{C}_{18}$ SPE column $(3 \mathrm{ml}$; Agilent) preconditioned with methanol and bicarbonate buffer at $\mathrm{pH} 12$. Salts were removed from the column by washing three times with $1 \mathrm{ml}$ of $0.1 \mathrm{M}$ borate buffer, $\mathrm{pH} 12$. Polyamines were eluted into cryovials with three washes of equal volumes of $1 \mathrm{M}$ acetic acid and acetonitrile, final volume $5 \mathrm{ml}$. 
Greater than $85 \%$ recovery for CAD, PUT, NSD, and SPD was observed, while AGM had $48 \%$ recovery (Table S1), perhaps because of the high pKa of AGM ( 12) compared to that of the other four compounds $(\sim 10)$. Artificial seawater (blanks) extracted using this method had only minimal concentrations (less than $4 \mathrm{nM}$ ) of NSD and SPD and none of the other three compounds (data not shown). Measured concentrations were not corrected for extraction recovery, so the values reported in this paper are conservative.

LC-MS/MS analysis. Quantification of polyamines was carried out using an Applied Biosystems 4000 Q-Trap triple quadrupole mass spectrometer with an electrospray ionization (ESI) interface, coupled to a Shimadzu LC-20AD liquid chromatograph (LC-MS/MS). The Applied Biosystems Analyst and ABSciex Multiquant software packages were used for instrument operation and quantification, respectively. A phenyl-3, 150 by 4.6-mm 5- $\mu \mathrm{m}$ high-pressure liquid chromatography (HPLC) column (GL Sciences) was used for chromatographic separations, using a $2.0-\mu \mathrm{m}$ prefilter as a guard column (Optimize Technologies). The sample rack was cooled to $10^{\circ} \mathrm{C}$ to prevent degradation of polyamines. The column temperature was maintained at $40^{\circ} \mathrm{C}$. HPLC mobile phases were MS grade water (Fisher) with $0.1 \%$ formic acid and MS grade acetonitrile (Fisher) with $0.1 \%$ formic acid. A 10 -min binary gradient with a flow rate of $0.8 \mathrm{ml} / \mathrm{min}$ was used. The initial concentration of $3 \%$ acetonitrile ramped to $30 \%$ acetonitrile in 5 $\mathrm{min}$. The column then reequilibrated at 3\% acetonitrile for $5 \mathrm{~min}$. The ESI source used a spray voltage of $5,200 \mathrm{~V}$ and a source temperature of $600^{\circ} \mathrm{C}$. The sheath gas pressure was $50 \mathrm{lb} / \mathrm{in}^{2}$, and the auxiliary gas pressure was $40 \mathrm{lb} / \mathrm{in}^{2}$. The mass spectrometer was run in positive ion mode. Compound-specific multiple reaction monitoring (MRM) parameters, column retention times, and limits of detection (LOD) are presented in Table 1. The instrumental limits of detection (Table 1) were calculated as three times the standard deviation of six runs of the lowest detectable standard $(5 \mathrm{nM})$. The sample injection volume was $10 \mu \mathrm{l}$, and samples were analyzed in triplicate. Samples and standards were all analyzed in a 50:50 acetonitrile:acetic acid mix. Samples were randomized prior to analysis. ${ }^{13} \mathrm{C}$-spermidine [spermidine(butyl- ${ }^{13}$ C4) trihydrochloride; Sigma-Aldrich] was added as an internal standard (IS) for quantification and to compensate for matrix effects. Compound concentrations that are listed as zero in figures and tables in this paper were below the LOD. LC-MS analysis was conducted at the Oregon State University Mass Spectrometry Core Facility. Data analysis was conducted in the R software environment (R Core Team, 2015), and all figures were created using the Ggplot2 software package for $R(84,85)$.

Flow cytometry analysis. Flow cytometry was used to monitor changes in cell size and morphology in HTCC7211 cultures in response to exposure to polyamines. Three treatments were used, all with cells grown under nutrient-replete conditions, with quadruplicate cultures for each treatment; cultures were started at a cell density of $5 \mathrm{E} 4$ cells $/ \mathrm{ml}$. The negative control had no polyamines added; in one experimental treatment (early addition), cultures were started with $250 \mathrm{nM}$ each polyamine added to the media; in the other experimental treatment (late addition), $250 \mathrm{nM}$ each polyamine was added after 4 days of growth, when they had passed $5 E 5$ cells/ml density. Samples were taken twice a week until they reached early stationary phase. Cells were stained with SYBR green I prior to analysis on a Becton, Dickinson influx cell sorter (BD ICS). The BD ICS was equipped with a 488-nm laser and detectors for forward scatter (FSC), side scatter (SSC), and fluorescence at $530 \mathrm{~nm}$, the emission wavelength of SYBR green I, and $692 \mathrm{~nm}$. Prior to sample analysis, the instrument was aligned according to the manufacturer's specifications. See references 74 and 75 for additional information on instrument specifications, alignment, and calibration procedures. Data were recorded for $>50,000$ cells per replicate per treatment. Flow cytometry files were analyzed using FlowJo (v.10.7.1), and cells were identified by their fluorescence in the 530-nm channel. The mean for each replicate for each detector channel was recorded and used in calculating the treatment means and standard deviations. Unfortunately, errors with the flow cytometer prevented observations of cells prior to day 4 of the experiment, and data are restricted to days 4, 7, 11, and 13. Cell concentrations determined on the flow cytometer are presented in Fig. S1G.

Computational modeling. The reaction catalyzed by spermidine synthase (Fig. S3) was computationally modeled to determine reaction energetics. Water and histidine were used separately as bases. Amine nitrogens in putrescine and spermidine were fully protonated, but the nitrogens in the adenosyl fragment were left unprotonated (neutral). First, conformational spaces for compounds I and III were explored using Spartan'14 (76), with the Merck molecular force field (MMFF) (Fig. S4). Density functional theory (DFT) studies were performed using Gaussian 16 (77). The B3LYP functional (78-81) was employed using the cc-pVDZ basis set (82). A self-consistent reaction field (SCRF) solvation model using water (83) was applied. All structures were optimized and showed only real vibrational frequencies. Selfconsistent field (SCF) energies with solvation correction were used as the primary measure of molecular energy. Reaction energies were estimated using the minimum energy conformer for each compound.

Data availability. The metabolomics data have been deposited in the EMBL-EBI MetaboLights database (doi: 10.1093/nar/gkz1019, PMID: 31691833) with the identifier MTBLS3146. The complete data set can be accessed at https://www.ebi.ac.uk/metabolights/MTBLS3146.

\section{SUPPLEMENTAL MATERIAL}

Supplemental material is available online only.

TEXT S1, DOCX file, $0.02 \mathrm{MB}$.

FIG S1, PDF file, $0.1 \mathrm{MB}$.

FIG S2, PDF file, $0.1 \mathrm{MB}$.

FIG S3, PDF file, $0.02 \mathrm{MB}$.

FIG S4, PDF file, $0.3 \mathrm{MB}$.

TABLE S1, DOCX file, $0.02 \mathrm{MB}$. 
TABLE S2, DOCX file, $0.02 \mathrm{MB}$.

TABLE S3, DOCX file, $0.02 \mathrm{MB}$.

TABLE S4, DOCX file, $0.01 \mathrm{MB}$.

TABLE S5, DOCX file, $0.01 \mathrm{MB}$.

\section{ACKNOWLEDGMENTS}

This work was funded by National Science Foundation grants OCE-1436865 and IOS1838445. This work was supported, in part, by the Oregon State University Research Office. The content is solely the responsibility of the authors and does not necessarily represent the official views of the OSU Mass Spectrometry Center. The authors acknowledge the OSU Mass Spectrometry Center at Oregon State University and the specific institutional instrument grant for Applied Biosystems 4000 Qtrap: NIH no. 1S10RR022589-01.

\section{REFERENCES}

1. Yoshida M, Kashiwagi K, Shigemasa A, Taniguchi S, Yamamoto K, Makinoshima H, Ishihama A, Igarashi K. 2004. A unifying model for the role of polyamines in bacterial cell growth, the polyamine modulon. J Biol Chem 279:46008-46013. https://doi.org/10.1074/jbc.M404393200.

2. Wortham BW, Oliveira MA, Patel CN. 2007. Polyamines in bacteria: pleiotropic effects yet specific mechanisms, p 106-115. In Perry RD, Fetherston JD (ed), The genus Yersinia. Springer, New York, NY.

3. Michael AJ. 2016. Polyamines in eukaryotes, bacteria, and archaea. J Biol Chem 291:14896-14903. https://doi.org/10.1074/jbc.R116.734780.

4. Liu Q, Nishibori N, Imai I, Hollibaugh J. 2016. Response of polyamine pools in marine phytoplankton to nutrient limitation and variation in temperature and salinity. Mar Ecol Prog Ser 544:93-105. https://doi.org/10.3354/ meps11583.

5. Nishibori N, Yuasa A, Sakai M, Fujihara S, Nishio S. 2001. Free polyamine concentrations in coastal seawater during phytoplankton bloom. Fisheries Sci 67:79-83. https://doi.org/10.1046/j.1444-2906.2001.00202.x.

6. Nishibori N, Matuyama Y, Uchida T, Moriyama T, Ogita Y, Oda M, Hirota H. 2003. Spatial and temporal variations in free polyamine distributions in Uranouchi Inlet, Japan. Marine Chem 82:307-314. https://doi.org/10 .1016/S0304-4203(03)00076-8.

7. Lu X, Zou L, Clevinger C, Liu Q, Hollibaugh JT, Mou X. 2014. Temporal dynamics and depth variations of dissolved free amino acids and polyamines in coastal seawater determined by high-performance liquid chromatography. Marine Chem 163:36-44. https://doi.org/10.1016/j.marchem .2014.04.004.

8. Large PJ. 1992. Enzymes and pathways of polyamine breakdown in microorganisms. FEMS Microbiol Rev 8:249-262. https://doi.org/10.1111/j.1574 -6968.1992.tb04991.x.

9. Mou X, Sun S, Rayapati P, Moran M. 2010. Genes for transport and metabolism of spermidine in Ruegeria pomeroyi DSS-3 and other marine bacteria. Aquat Microb Ecol 58:311-321. https://doi.org/10.3354/ame01367.

10. Liu Q, Lu X, Tolar BB, Mou X, Hollibaugh JT. 2015. Concentrations, turnover rates and fluxes of polyamines in coastal waters of the South Atlantic Bight. Biogeochemistry 123:117-133. https://doi.org/10.1007/s10533-014 -0056-1.

11. Lu X, Wang K, Sun S, Mou X. 2020. Metatranscriptomic identification of polyamine-transforming bacterioplankton in the Gulf of Mexico. Environ Microbiol Rep 12:258-266. https://doi.org/10.1111/1758-2229.12841.

12. Chou HT, Kwon D-H, Hegazy M, Lu C-D. 2008. Transcriptome analysis of agmatine and putrescine catabolism in Pseudomonas aeruginosa PAO1. J Bacteriol 190:1966-1975. https://doi.org/10.1128/JB.01804-07.

13. Bridoux MC, Keil RG, Ingalls AE. 2012. Analysis of natural diatom communities reveals novel insights into the diversity of long chain polyamine (LCPA) structures involved in silica precipitation. Organic Geochemistry 47:9-21. https://doi.org/10.1016/j.orggeochem.2012.02.010.

14. Morris RM, Rappé MS, Connon SA, Vergin KL, Siebold WA, Carlson CA, Giovannoni SJ. 2002. SAR11 clade dominates ocean surface bacterioplankton communities. Nature 420:806-810. https://doi.org/10.1038/ nature 01240 .

15. Giovannoni SJ. 2017. SAR11 bacteria: the most abundant plankton in the oceans. Annu Rev Mar Sci 9:231-255. https://doi.org/10.1146/annurev -marine-010814-015934.
16. Zhao X, Schwartz CL, Pierson J, Giovannoni SJ, Mclntosh JR, Nicastro D. 2017. Three-dimensional structure of the ultraoligotrophic marine bacterium "Candidatus Pelagibacter ubique". Appl Environ Microbiol 83: e02807-16. https://doi.org/10.1128/AEM.02807-16.

17. Sowell SM, Norbeck AD, Lipton MS, Nicora CD, Callister SJ, Smith RD, Barofsky DF, Giovannoni SJ. 2008. Proteomic analysis of stationary phase in the marine bacterium "Candidatus Pelagibacter ubique". Appl Environ Microbiol 74:4091-4100. https://doi.org/10.1128/AEM.00599-08.

18. Sowell SM, Wilhelm LJ, Norbeck AD, Lipton MS, Nicora CD, Barofsky DF, Carlson CA, Smith RD, Giovanonni SJ. 2009. Transport functions dominate the SAR11 metaproteome at low-nutrient extremes in the Sargasso Sea. ISME J 3:93-105. https://doi.org/10.1038/ismej.2008.83.

19. Bosdriesz E, Magnúsdóttir S, Bruggeman FJ, Teusink B, Molenaar D. 2015. Binding proteins enhance specific uptake rate by increasing the substrate-transporter encounter rate. FEBS J 282:2394-2407. https://doi.org/ 10.1111/febs.13289.

20. Noell SE, Giovannoni SJ. 2019. SAR11 bacteria have a high affinity and multifunctional glycine betaine transporter. Environ Microbiol 21: 2559-2575. https://doi.org/10.1111/1462-2920.14649.

21. Norris N, Levine NM, Fernandez VI, Stocker R. 2021. Mechanistic model of nutrient uptake explains dichotomy between marine oligotrophic and copiotrophic bacteria. Microbiology 17:e1009023. https://doi.org/10 .1371/journal.pcbi.1009023.

22. Giovannoni SJ, Tripp HJ, Givan S, Podar M, Vergin KL, Baptista D, Bibbs L, Eads J, Richardson TH, Noordewier M, Rappé MS, Short JM, Carrington JC, Mathur EJ. 2005. Genome streamlining in a cosmopolitan oceanic bacterium. Science 309:1242-1245. https://doi.org/10.1126/science.1114057.

23. Espinosa-Cantú A, Cruz-Bonilla E, Noda-Garcia L, DeLuna A. 2020. Multiple forms of multifunctional proteins in health and disease. Front Cell Dev Biol 8:451. https://doi.org/10.3389/fcell.2020.00451.

24. Ferla MP, Brewster JL, Hall KR, Evans GB, Patrick WM. 2017. Primordial-like enzymes from bacteria with reduced genomes. Mol Microbiol 105: 508-524. https://doi.org/10.1111/mmi.13737.

25. Khersonsky O, Tawfik DS. 2010. Enzyme promiscuity: a mechanistic and evolutionary perspective. Annu Rev Biochem 79:471-505. https://doi.org/ 10.1146/annurev-biochem-030409-143718.

26. McCarthy M, Pratum T, Hedges J, Benner R. 1997. Chemical composition of dissolved organic nitrogen in the ocean. Nature 390:150-154. https:// doi.org/10.1038/36535.

27. Smith DP, Thrash JC, Nicora CD, Lipton MS, Burnum-Johnson KE, Carini P, Smith RD, Giovannoni SJ. 2013. Proteomic and transcriptomic analyses of "Candidatus Pelagibacter ubique" describe the first PIl-independent response to nitrogen limitation in a free-living Alphaproteobacterium. mBio 4:e00133-12. https://doi.org/10.1128/mBio.00133-12.

28. Mou X, Vila-Costa M, Sun S, Zhao W, Sharma S, Moran MA. 2011. Metatranscriptomic signature of exogenous polyamine utilization by coastal bacterioplankton. Environ Microbiol Rep 3:798-806. https://doi.org/10 $.1111 /$ j.1758-2229.2011.00289.x.

29. Lu X, Sun S, Hollibaugh JT, Mou X. 2015. Identification of polyamine-responsive bacterioplankton taxa in South Atlantic Bight. Environ Microbiol Rep 7:831-838. https://doi.org/10.1111/1758-2229.12311.

30. Mou X, Jacob J, Lu X, Vila-Costa M, Chan L-K, Sharma S, Zhang Y. 2015. Bromodeoxyuridine labelling and fluorescence-activated cell sorting of 
polyamine-transforming bacterioplankton in coastal seawater. Environ Microbiol 17:876-888. https://doi.org/10.1111/1462-2920.12550.

31. Kell DB, Brown M, Davey HM, Dunn WB, Spasic I, Oliver SG. 2005. Metabolic footprinting and systems biology: the medium is the message. Nat Rev Microbiol 3:557-565. https://doi.org/10.1038/nrmicro1177.

32. Fiehn O. 2001. Combining genomics, metabolome analysis, and biochemical modelling to understand metabolic networks. Comp Funct Genomics 2:155-168. https://doi.org/10.1002/cfg.82.

33. Knorr S, Sinn M, Galetskiy D, Williams RM, Wang C, Müller N, Mayans O, Schleheck D, Hartig JS. 2018. Widespread bacterial lysine degradation proceeding via glutarate and L-2-hydroxyglutarate. Nat Commun 9:5071. https://doi.org/10.1038/s41467-018-07563-6.

34. Hamana K, Matsuzaki S. 1982. Widespread occurrence of norspermidine and norspermine in eukaryotic algae. J Biochem 91:1321-1328. https:// doi.org/10.1093/oxfordjournals.jbchem.a133818.

35. Hamana K, Sakamoto A, Nishina M, Niitsu M. 2004. Cellular polyamine profile of the phyla Dinophyta, Apicomplexa, Ciliophora, Euglenozoa, Cercozoa and Heterokonta. J Gen Appl Microbiol 50:297-303. https://doi .org/10.2323/jgam.50.297.

36. Stocker R. 2012. Marine microbes see a sea of gradients. Science 338: 628-633. https://doi.org/10.1126/science.1208929.

37. White AE, Giovannoni SJ, Zhao Y, Vergin K, Carlson CA. 2019. Elemental content and stoichiometry of SAR11 chemoheterotrophic marine bacteria. Limnol Oceanogr 4:44-51. https://doi.org/10.1002/lol2.10103.

38. Revelles O, Espinosa-Urgel M, Fuhrer T, Sauer U, Ramos JL. 2005. Multiple and interconnected pathways for I-lysine catabolism in Pseudomonas putida KT2440. J Bacteriol 187:7500-7510. https://doi.org/10.1128/JB.187 .21.7500-7510.2005.

39. Shah P, Swiatlo E. 2008. A multifaceted role for polyamines in bacterial pathogens. Mol Microbiol 68:4-16. https://doi.org/10.1111/j.1365-2958 .2008.06126.x.

40. Qian Z-G, Xia X-X, Lee SY. 2011. Metabolic engineering of Escherichia coli for the production of cadaverine: a five carbon diamine. Biotechnol Bioeng 108:93-103. https://doi.org/10.1002/bit.22918.

41. Guzmán GI, Utrilla J, Nurk S, Brunk E, Monk JM, Ebrahim A, Palsson BO, Feist AM. 2015. Model-driven discovery of underground metabolic functions in Escherichia coli. Proc Natl Acad Sci U S A 112:929-934. https://doi .org/10.1073/pnas.1414218112.

42. Francke C, Siezen RJ, Teusink B. 2005. Reconstructing the metabolic network of a bacterium from its genome. Trends Microbiol 13:550-558. https://doi.org/10.1016/j.tim.2005.09.001.

43. Lee J, Sperandio V, Frantz DE, Longgood J, Camilli A, Phillips MA, Michael AJ. 2009. An alternative polyamine biosynthetic pathway is widespread in bacteria and essential for biofilm formation in Vibrio cholerae. J Biol Chem 284:9899-9907. https://doi.org/10.1074/jbc.M900110200.

44. Bowman WH, Tabor CW, Tabor H. 1973. Spermidine biosynthesis. Purification and properties of propylamine transferase from Escherichia coli. J Biol Chem 248:2480-2486. https://doi.org/10.1016/S0021-9258(19)44133-1.

45. Lee M-J, Huang C-Y, Sun Y-J, Huang H. 2005. Cloning and characterization of spermidine synthase and its implication in polyamine biosynthesis in Helicobacter pylori strain 26695. Protein Expr Purif 43:140-148. https:// doi.org/10.1016/j.pep.2005.04.017.

46. Krossa S, Faust A, Ober D, Scheidig AJ. 2016. Comprehensive structural characterization of the bacterial homospermidine synthase: an essential enzyme of the polyamine metabolism. Sci Rep 6:19501. https://doi.org/10 .1038/srep19501.

47. Burnat M, Li B, Kim SH, Michael AJ, Flores E. 2018. Homospermidine biosynthesis in the cyanobacterium Anabaena requires a deoxyhypusine synthase homologue and is essential for normal diazotrophic growth. Mol Microbiol 109:763-780. https://doi.org/10.1111/mmi.14006.

48. Brochier C, López-García P, Moreira D. 2004. Horizontal gene transfer and archaeal origin of deoxyhypusine synthase homologous genes in bacteria. Gene 330:169-176. https://doi.org/10.1016/j.gene.2004.01.018.

49. Grossowicz N, Razin S, Rozansky R. 1955. Factors influencing the antibacterial action of spermine and spermidine on Staphylococcus aureus. J Gen Microbiol 13:436-441. https://doi.org/10.1099/00221287-13-3-436.

50. Qian Z-G, Xia X-X, Lee SY. 2009. Metabolic engineering of Escherichia coli for the production of putrescine: a four carbon diamine. Biotechnol Bioeng 104:651-662. https://doi.org/10.1002/bit.22502.

51. Ray JCJ, Wickersheim ML, Jalihal AP, Adeshina YO, Cooper TF, Balázsi G. 2016. Cellular growth arrest and persistence from enzyme saturation. PLoS Comput Biol 12:e1004825. https://doi.org/10.1371/journal.pcbi .1004825 .
52. Busse J, Auling G. 1988. Polyamine pattern as a chemotaxonomic marker within the proteobacteria. Syst Appl Microbiol 11:1-8. https://doi.org/10 .1016/S0723-2020(88)80040-7.

53. Sun J, Todd JD, Thrash JC, Qian Y, Qian MC, Temperton B, Guo J, Fowler EK, Aldrich JT, Nicora CD, Lipton MS, Smith RD, De Leenheer P, Payne SH, Johnston AWB, Davie-Martin CL, Halsey KH, Giovannoni SJ. 2016. The abundant marine bacterium Pelagibacter simultaneously catabolizes dimethylsulfoniopropionate to the gases dimethyl sulfide and methanethiol. Nat Microbiol 1:16065. https://doi.org/10.1038/nmicrobiol.2016.210.

54. Satishchandran C, Boyle SM. 1986. Purification and properties of agmatine ureohydrolyase, a putrescine biosynthetic enzyme in Escherichia coli. J Bacteriol 165:843-848. https://doi.org/10.1128/jb.165.3.843-848.1986.

55. DeSa RJ. 1972. Putrescine oxidase from Micrococcus rubens. J Biol Chem 247:5527-5534. https://doi.org/10.1016/S0021-9258(20)81137-5.

56. Eady RR, Large PJ. 1968. Purification and properties of an amine dehydrogenase from Pseudomonas AM1 and its role in growth on methylamine. Biochem J 106:245-255. https://doi.org/10.1042/bj1060245.

57. Wu WH, Morris DR. 1973. Biosynthetic arginine decarboxylase from Escherichia coli. J Biol Chem 248:1687-1695. https://doi.org/10.1016/S0021 -9258(19)44245-2.

58. Levin GV, Shapiro J. 1965. Metabolic uptake of phosphorus by wastewater organisms. J Water Pollut Control Fed 37:800-821.

59. Brown N, Shilton A. 2014. Luxury uptake of phosphorus by microalgae in waste stabilisation ponds: current understanding and future direction. Rev Environ Sci Biotechnol 13:321-328. https://doi.org/10.1007/s11157 -014-9337-3.

60. Grover JP. 2009. Is storage an adaptation to spatial variation in resource availability? Am Nat 173:E44-E61. https://doi.org/10.1086/595751.

61. Wotanis CK, Brennan WP, Angotti AD, Villa EA, Zayner JP, Mozina AN, Rutkovsky AC, Sobe RC, Bond WG, Karatan E. 2017. Relative contributions of norspermidine synthesis and signaling pathways to the regulation of Vibrio cholerae biofilm formation. PLoS One 12:e0186291. https://doi .org/10.1371/journal.pone.0186291.

62. Igarashi K, Kashiwagi K. 1999. Polyamine transport in bacteria and yeast. Biochem J 344:633-642. https://doi.org/10.1042/0264-6021:3440633.

63. Malmstrom RR, Kiene RP, Cottrell MT, Kirchman DL. 2004. Contribution of SAR11 bacteria to dissolved dimethylsulfoniopropionate and amino acid uptake in the North Atlantic Ocean. Appl Environ Microbiol 70:4129-4135 . https://doi.org/10.1128/AEM.70.7.4129-4135.2004.

64. Carini P, Steindler L, Beszteri S, Giovannoni SJ. 2013. Nutrient requirements for growth of the extreme oligotroph 'Candidatus Pelagibacter ubique' HTCC1062 on a defined medium. ISME J 7:592-602. https://doi.org/ 10.1038/ismej.2012.122.

65. Sun J, Steindler L, Thrash JC, Halsey KH, Smith DP, Carter AE, Landry ZC, Giovannoni SJ. 2011. One carbon metabolism in SAR11 pelagic marine bacteria. PLoS One 6:e23973. https://doi.org/10.1371/journal.pone.0023973.

66. Carini P, Campbell EO, Morré J, Sañudo-Wilhelmy SA, Thrash JC, Bennett SE, Temperton B, Begley T, Giovannoni SJ. 2014. Discovery of a SAR11 growth requirement for thiamin's pyrimidine precursor and its distribution in the Sargasso Sea. ISME J 8:1727-1738. https://doi.org/10.1038/ ismej.2014.61.

67. Braakman R, Satinsky BM, Longnecker K, Becker JW, Dooley K, Arellano A, Hogle SL, Kido Soule MC, Kujawinski EB, Chisholm SW. 2018. Emergence of a cryptic nitrogen cycle in the co-evolution of Prochlorococcus and sympatric heterotrophs. Abstr AGU Fall Meeting, abst B51D-08.

68. Carini P, White AE, Campbell EO, Giovannoni SJ. 2014. Methane production by phosphate-starved SAR11 chemoheterotrophic marine bacteria. Nat Commun 5:4346. https://doi.org/10.1038/ncomms5346.

69. Green R, Hanfrey CC, Elliott KA, McCloskey DE, Wang X, Kanugula S, Pegg $A E$, Michael AJ. 2011. Independent evolutionary origins of functional polyamine biosynthetic enzyme fusions catalysing de novo diamine to triamine formation. Mol Microbiol 81:1109-1124. https://doi.org/10.1111/ j.1365-2958.2011.07757.x.

70. Shaw FL, Elliott KA, Kinch LN, Fuell C, Phillips MA, Michael AJ. 2010. Evolution and multifarious horizontal transfer of an alternative biosynthetic pathway for the alternative polyamine sym-homospermidine. J Biol Chem 285:14711-14723. https://doi.org/10.1074/jbc.M110.107219.

71. Giovannoni SJ, Halsey KH, Saw J, Muslin O, Suffridge CP, Sun J, Lee C-P, Moore ER, Temperton B, Noell SE. 2019. A parasitic arsenic cycle that shuttles energy from phytoplankton to heterotrophic bacterioplankton. mBio 10:e00246-19. https://doi.org/10.1128/mBio.00246-19.

72. Longnecker K, Kido Soule MC, Kujawinski EB. 2015. Dissolved organic matter produced by Thalassiosira pseudonana. Marine Chemistry 168: 114-123. https://doi.org/10.1016/j.marchem.2014.11.003. 
73. Molins-Legua C, Campins-Falcó P. 2005. Solid phase extraction of amines. Anal Chim Acta 546:206-220. https://doi.org/10.1016/j.aca.2005.05.021.

74. Graff JR, Behrenfeld MJ. 2018. Photoacclimation responses in subarctic Atlantic phytoplankton following a natural mixing-restratification event. Front Mar Sci 5:209. https://doi.org/10.3389/fmars.2018.00209.

75. Schulien JA, Della Penna A, Gaube P, Chase AP, Haëntjens N, Graff JR, Hair JW, Hostetler CA, Scarino AJ, Boss ES, Karp-Boss L, Behrenfeld MJ. 2020. Shifts in phytoplankton community structure across an anticyclonic eddy revealed from high spectral resolution lidar scattering measurements. Front Mar Sci 7:493. https://doi.org/10.3389/fmars.2020.00493.

76. Hehre WJ, Burke LD, Shusterman AJ, Pietro WJ. 2014. Spartan. Wavefunction, Inc., Irvine, CA.

77. Frisch MJ, Trucks GW, Schlegel HB, Scuseria GE, Robb MA, Cheeseman JR, Scalmani G, Barone V, Petersson GA, Nakatsuji H, Li X, Caricato M, Marenich AV, Bloino J, Janesko BG, Gomperts R, Mennucci B, Hratchian HP, Ortiz JV, Izmaylov AF, Sonnenberg JL, Williams Ding F, Lipparini $F$, Egidi F, Goings J, Peng B, Petrone A, Henderson T, Ranasinghe $D_{\text {, }}$ Zakrzewski VG, Gao J, Rega N, Zheng G, Liang W, Hada M, Ehara M, Toyota K, Fukuda R, Hasegawa J, Ishida M, Nakajima T, Honda Y, Kitao O, Nakai H, Vreven T, Throssell K, Montgomery JA, Jr, Peralta JE, Ogliaro F, Bearpark MJ, Heyd JJ, Brothers EN, Kudin KN, et al. 2016. Gaussian 16 Rev. C.01. Gaussian, Inc., Wallingford, CT.
78. Becke AD. 1993. A new mixing of Hartree-Fock and local density-functional theories. The J Chem Phys 98:1372-1377. https://doi.org/10.1063/1 .464304.

79. Lee C, Yang W, Parr RG. 1988. Development of the Colle-Salvetti correlation-energy formula into a functional of the electron density. Phys Rev B Condens Matter 37:785-789. https://doi.org/10.1103/physrevb.37.785.

80. Vosko SH, Wilk L, Nusair M. 1980. Accurate spin-dependent electron liquid correlation energies for local spin density calculations: a critical analysis. Can J Phys 58:1200-1211. https://doi.org/10.1139/p80-159.

81. Stephens PJ, Devlin FJ, Chabalowski CF, Frisch MJ. 1994. Ab initio calculation of vibrational absorption and circular dichroism spectra using density functional force fields. J Phys Chem 98:11623-11627. https://doi.org/ $10.1021 / \mathrm{j} 100096 \mathrm{a} 001$.

82. Dunning TH. 1989. Gaussian basis sets for use in correlated molecular calculations. I. The atoms boron through neon and hydrogen. J Chem Phys 90:1007-1023. https://doi.org/10.1063/1.456153.

83. Tomasi J, Mennucci B, Cammi R. 2005. Quantum mechanical continuum solvation models. Chem Rev 105:2999-3094. https://doi.org/10.1021/ cr9904009.

84. R Core Team. 2018. R: a language and environment for statistical computing. R Foundation for Statistical Computing, Vienna, Austria. https://www .R-project.org/.

85. Wickham H. 2016. ggplot2: elegant graphics for data analysis. Springer-Verlag, New York, NY. 